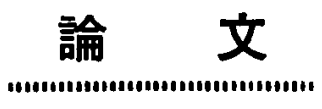

\title{
トルエンの接触酸化脱水素二量化反応における $\mathrm{Bi}_{2} \mathrm{O}_{3}-\mathrm{SnO}_{2}$ 触媒の形態変化 ${ }^{*}$
}

\author{
劉懐 徳**, 河 合 是**, 山崎康 男** \\ Change of Structures of $\mathrm{Bi}_{2} \mathrm{O}_{3}-\mathrm{SnO}_{2}$ Catalysts in Toluene \\ Oxidative Dehydrodimerization*
}

by Kindtoken Hwai-Der Liu**, Tadashi Kawai** and Yasuo Yamazaki**

\begin{abstract}
Summary : Structures of $\mathrm{Bi}_{2} \mathrm{O}_{3}-\mathrm{SnO}_{2}$ catalysts consisting of various $\mathrm{Bi} / \mathrm{Sn}$ atomic ratio were investigated by means of $\mathrm{X}$-ray diffraction analysis. The binary mixture of $\mathrm{Bi}_{2} \mathrm{O}_{3}-\mathrm{SnO}_{2}$ was converted to $\mathrm{Bi}_{2} \mathrm{Sn}_{2} \mathrm{O}_{7}, \mathrm{Bi}_{2} \mathrm{Sn}_{2} \mathrm{O}_{7}+\alpha-\mathrm{Bi}_{2} \mathrm{O}_{3}$, or $\mathrm{Bi}_{2} \mathrm{Sn}_{2} \mathrm{O}_{7}+\mathrm{SnO}_{2}$ according to their atomic ratio during calcination. $\mathrm{Bi}_{2} \mathrm{Sn}_{2} \mathrm{O}_{7}$ in these catalysts was converted to $\mathrm{SnO}_{2}, r-\mathrm{Bi}_{2} \mathrm{O}_{3}$, and $\mathrm{Bi}_{12} \mathrm{SnO}_{20}$ during the course of toluene oxidation.

Catalytic activity of these catalysts for oxidative dehydrodimerization of toluene to bibenzyl and stilbene was determined in the temperature range $500 \sim 600^{\circ} \mathrm{C}$ using a conventional flow system with the fixed bed at the atmospheric pressure. A correlation between the catalytic activity and structures of these catalysts was made subsequently, combined with some reduction tests of these catalysts with toluene. It is suggested that $\mathrm{Bi}_{2} \mathrm{Sn}_{2} \mathrm{O}_{7}$ is the main active and selective component at $500^{\circ} \mathrm{C}$, while $\alpha-\mathrm{Bi}_{2} \mathrm{O}_{3}, r-\mathrm{Bi}_{2} \mathrm{O}_{3}$, and $\mathrm{Bi}_{12} \mathrm{SnO}_{20}$ are active and selective at $600^{\circ} \mathrm{C}$. The lattice oxygen combined with bismuth plays a role in the oxidation of toluene to dehydrodimer, and $\mathrm{SnO}_{2}$, as an oxygen-activating component, in the reoxidation of reduced bismuth.
\end{abstract}

\section{1 緒言}

プロピレンやイソブテンの接触酸化脱水素二量化によるベン ゼン, p-キシレンの生成はアリル型酸化の反応として興味があ る゙〜3。これについては清山らによって解説されているい。

著者らはこの反応をベンジル型酸化に適用し, $\mathrm{Bi}_{2} \mathrm{O}_{3}-\mathrm{SnO}_{2}$ 触媒によるトルエンの酸化を試み，比較的好選択率でビベンジ ルおよびスチルベンを得た ${ }^{5), 6) 。 ~}$

本報に扔いてはトルエンの酸化二量化に対する $\mathrm{Bi}_{2} \mathrm{O}_{3}-\mathrm{SnO}_{2}$ 触媒の作用について研究し,この触媒が複合酸化物として作用 し，かつその化合形的が応時間の経過とともに変化していく ことを明らかにしたので報告する。

\section{2 実験}

\section{1 触媒}

触媒は市肘の試薬一級 $\mathrm{Bi}_{2} \mathrm{O}_{3}$ および $\mathrm{SnO}_{2}$ を所定の割合で 混合し，10 wt\% の粘結郕アビセルを加えて混練法により調 製した。110 $\mathrm{C}, 12$ 時間乾燥したのち, 空気ふん囲気中 550 $700^{\circ} \mathrm{C}, 1 \sim 6$ 時間焼成した。焼成後の触媒の表面積は淮体空素 温度で BET 法によって測定した。

\section{2 試䍜}

*昭和 51 年 11 月 10 日受理

** 東京都立大学工学部工業化学科 (158 東京都世田谷区深沢 2-1-1) Department of Industrial Chemistry, Faculty of Technology, Tokyo Metropolitan University (2-1-1, Fukazawa, Setagayaku, Tokyo 158)
市販の特級トルエン（純度 99.95\%）をそのまま反応原料と して使用した。市販のボンベうめめ酸素, 窒素および空気はシ リカゲルで乾燥してから反応に使用した。

\section{3 反応装置およひ操作法}

反応は通常の常圧固定床流通系反応装置を用い, $500 \sim 600^{\circ} \mathrm{C}$ で行った。反応管として長さ $500 \mathrm{~mm}$, 内径 $15 \mathrm{~mm}$, 中心に熱 電対保讙管をそう入してある石英管を用いた。反応に使用した

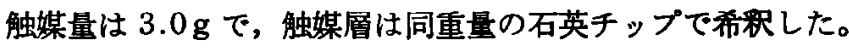
触媒層の上下に石英チップを充てんした。

触媒を充てんした反応管を窒素気流中所定温度で約 30 分処 理した後,トルエンを定量ポンプによって反応管の上部に送入 し，予熱部で気化させてから触媒層を通過させた。窒素, 酸素 あるいは空気は流量計を通してから反応管の上部に送入した。 反応生成物は寒剂で泠却捕集し，非凝縮ガスは定量後系外に 放出した。

\section{4 分 析}

分析は主としてガスクロマトグラフィーによった。Apiezon Grease L カラム $\left(3 \mathrm{~m}, 80 \sim 230^{\circ} \mathrm{C}\right)$ および PEG $20 \mathrm{M}$ カラ 厶 $\left(3 \mathrm{~m}, 70 \sim 230^{\circ} \mathrm{C}\right)$ を液状生成物の分析に用いた。ガス状 生成物は Molecular Sieve $5 \mathrm{~A}$ カラム $\left(3 \mathrm{~m}, 20^{\circ} \mathrm{C}\right)$ および Porapak $Q$ カラム $\left(3 \mathrm{~m}, 20^{\circ} \mathrm{C}\right)$ によって分析した。安息香酸 などの酸性物澌の生成量は $0.01 N \mathrm{NaOH}$ 溶液によって抽出 分離した後，過剩のてルカリを定量して求めた。生成物の選択 率は炭素基準で算出した。

\section{$2.5 \times$ 線分析}


触某の化合形態は対陰極として Cu を使い，粉末法によって X線回折測定を行った。測定条件は室温, $35 \mathrm{kV}, 15 \mathrm{~mA}$ であ った。

\section{3 結果と考察}

\section{1 各種組成の $\mathrm{Bi}_{2} \mathrm{O}_{3}-\mathrm{SnO}_{2}$ 触媒の活性と選択性}

種々の混合割合の $\mathrm{Bi}_{2} \mathrm{O}_{3}-\mathrm{SnO}_{2}$ 混合物を $700^{\circ} \mathrm{C}$ で 6 時間焼 成し，これらの触媒によるトルエンの酸化脱水秦二量化反応を $500^{\circ} \mathrm{C}$ で行った。結果を Fig. 1 に示す。

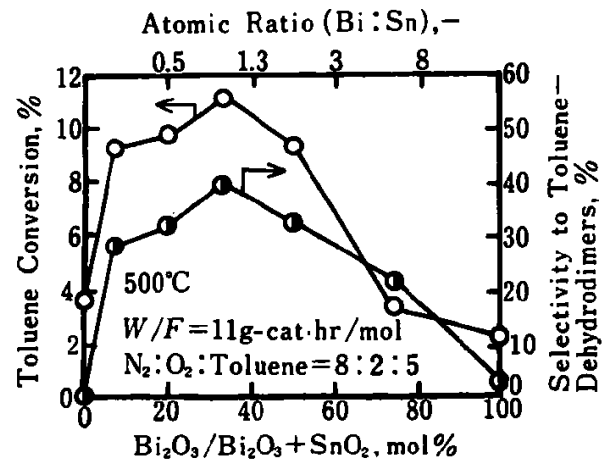

Fig. 1 Activity of $\mathrm{Bi}_{2} \mathrm{O}_{2}-\mathrm{SnO}_{2}$ Catalysts for Oxidative Dehydrodimerization of Toluene

トルエン転化率, 脱水素二量体（ビベンジル十スチルベン） 選択率ともに $\mathrm{Bi}_{2} \mathrm{O}_{3}$ 含有量の増加とともに増大し, $\mathrm{Bi}_{2} \mathrm{O}_{3}$ 含有 率 $33 \mathrm{~mol} \%$ ( $\mathrm{Bi}: \mathrm{Sn}$ 原子比 1 ) の付近で極大を示し, 以下 $\mathrm{Bi}_{2} \mathrm{O}_{3}$ 含有量の增加とともに減少する。この傾向は大段ら ${ }^{21}$ に よって検討された $\mathrm{Bi}_{2} \mathrm{O}_{3}-\mathrm{SnO}_{2}$ 触媒によるイソブテンの酸化脱 水素二量化反応における生成 $p$-キシレン選択率と $\mathrm{Bi}: \mathrm{Sn}$ 原 子比の関係に類似してい る。 Catalysts

スチルペンとビベンジ ルの生成比は Fig. 2 に 示すよ 5 に $\mathrm{Bi}_{2} \mathrm{O}_{3}$ 含有 量の増加とともに減少し た。このことは $\mathrm{SnO}_{2}$ が ビベンジルのスチルベン への酸化脱水素にに対し て主要な役割を果たして いると思われる。

\begin{tabular}{c|c}
\multicolumn{2}{c}{ Catalysts } \\
\hline $\begin{array}{c}\text { Composition } \\
\mathrm{Bi}_{2} \mathrm{O}_{3} / \mathrm{Bi}_{2} \mathrm{O}_{3}+\mathrm{SnO}_{2}\end{array}$ & Surface Area* \\
$\left(\mathrm{mol}^{*}\right)$ & $\left(\mathrm{m}^{2} / \mathrm{g}^{*}\right)$ \\
\hline 0 & 8.8 \\
7.7 & 11.6 \\
20 & 5.2 \\
33.3 & 1.9 \\
50 & 1.3 \\
75 & 1.0 \\
100 & 0.9 \\
\hline
\end{tabular}

* $700^{\circ} \mathrm{C}, 6 \mathrm{hr}-$ Calcined.

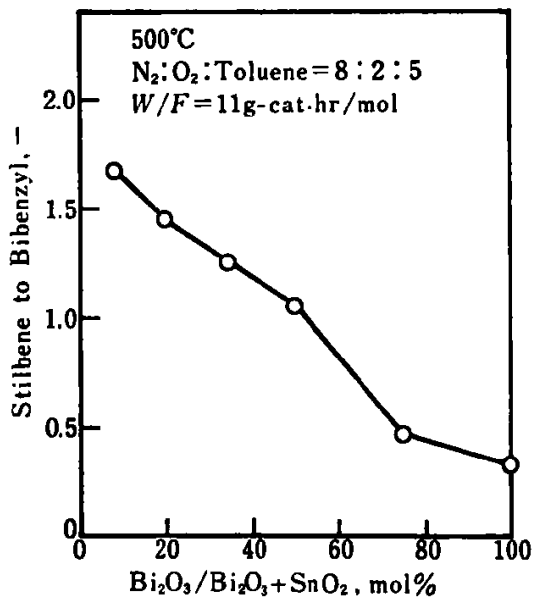

Fig. 2 Effect of $\mathrm{Bi}_{2} \mathrm{O}_{3}$ Content on the Production Ratio of Toluene Dehydrodimers
各種混合割合の $\mathrm{Bi}_{2} \mathrm{O}_{3}-\mathrm{SnO}_{2}$ 触媒の表面稓は Table 1 に示 すように,いずれもそれ程大きな值ではなく， $\mathrm{Bi}_{2} \mathrm{O}$, 含有率 7.7 molg 付近に極大值をもち, $\mathrm{Bi}_{2} \mathrm{O}_{3}$ の増加とともに著しく減少 している。このことと Fig. 1 の結果から転化率，選択率と表 面積の間には值接的な関係はないと考えられる。

\section{2 焼成 $\mathrm{Bi}_{2} \mathrm{O}_{3}-\mathrm{SnO}_{2}$ 混合物の化合形帮}

$\mathrm{Bi}: \mathrm{Sn}$ 原子比 1 の触媒の活性および選択性が極大值を示す 理由を明らかにするため， $700^{\circ} \mathrm{C} て ゙ 6$ 時間焼成した各種混合割 合の $\mathrm{Bi}_{2} \mathrm{O}_{3}-\mathrm{SnO}_{2}$ 混合物の形热を $\mathrm{X}$ 線回折法により分析し た。結果の一例を Fig. 3 に示す。

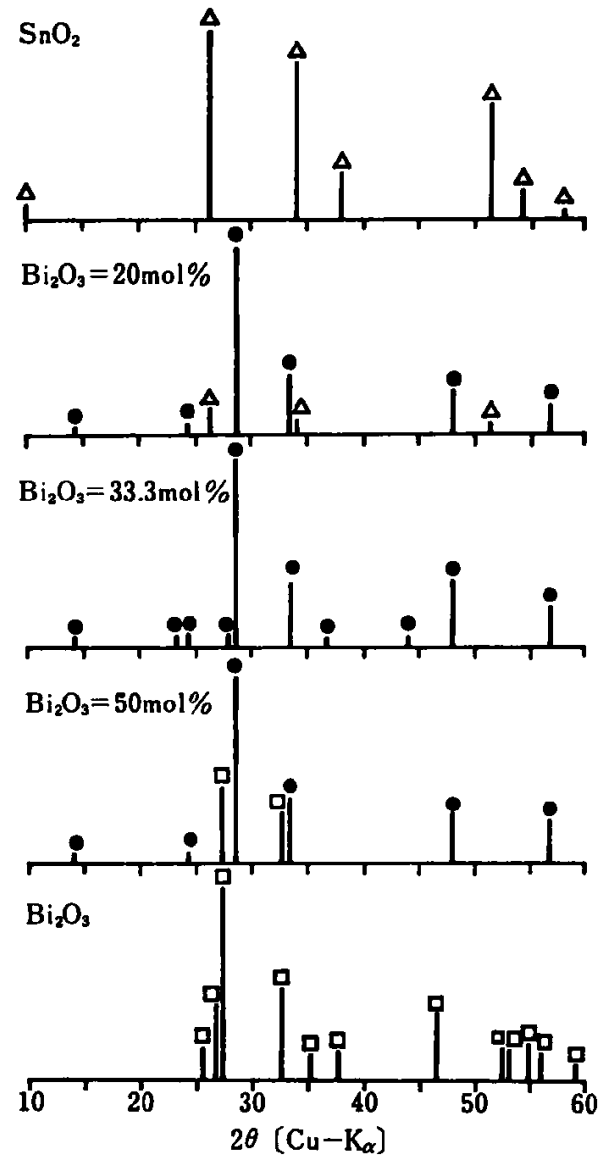

Fig. 3 The $\mathrm{X}$-ray Diffraction Patterns of $\mathrm{Bi}_{2} \mathrm{O}_{2}-\mathrm{SnO}_{2}$ Catalysts

$\mathrm{SnO}_{2}$ および $\alpha-\mathrm{Bi}_{2} \mathrm{O}_{3}$ はそれぞれ $2 \theta=26.7^{\circ}$ および $27.3^{\circ}$ に強い回折線を示す。一方 $\mathrm{Bi}_{2} \mathrm{O}_{3}$ 含有事 $33 \mathrm{~mol} \%$ のものの $\mathrm{X}$ 線回折には $2 \theta=28.9^{\circ}$ に $\mathrm{SnO}_{2}$ および $\alpha-\mathrm{Bi}_{2} \mathrm{O}_{3}$ にはない強い 回折線が現れ， $\mathrm{SnO}_{2}$ および $\propto-\mathrm{Bi}_{2} \mathrm{O}_{3}$ に特有の回折線はなくな っている。この混合物の回折パターンを ASTM X-ray Powder Data File に対応させると $\mathrm{Bi}_{2} \mathrm{Sn}_{2} \mathrm{O}_{7}$ のそれに一致した”。 すなわち $\mathrm{SnO}_{2}$ と $\mathrm{Bi}_{2} \mathrm{O}_{3}$ を $\mathrm{Bi}: \mathrm{Sn}$ 原子比 1 の割合で混合し， これを $700^{\circ} \mathrm{C}$ で 6 時間焼成することにより $\mathrm{Bi}_{2} \mathrm{Sn}_{2} \mathrm{O}_{7}$ が生成す ることがわかった。

$$
\mathrm{Bi}_{2} \mathrm{O}_{3}+\mathrm{SnO}_{2} \stackrel{\Delta}{\rightarrow} \mathrm{Bi}_{2} \mathrm{Sn}_{2} \mathrm{O}_{7}
$$

$\mathrm{Bi}_{2} \mathrm{O}_{3}$ 含有率が $33 \mathrm{~mol} \%$ 以下の混合物（たとえば $20 \mathrm{~mol} \%$ ） では $\mathrm{Bi}_{2} \mathrm{Sn}_{2} \mathrm{O}_{7}$ と $\mathrm{SnO}_{2}$ の回折 パターンが, 同含有事が 33 mol\% 以上の混合物（たとえば $50 \mathrm{~mol} \%$ ）では $\mathrm{Bi}_{2} \mathrm{Sn}_{2} \mathrm{O}$ ，と $\alpha-\mathrm{Bi}_{2} \mathrm{O}_{3}$ の回折パターンが褯められた。したがって各種割合の 混合物を焼成したものは $\mathrm{Bi}_{2} \mathrm{Sn}_{2} \mathrm{O}_{7}$ か, $\mathrm{Bi}_{2} \mathrm{Sn}_{2} \mathrm{O}_{7}$ と $\mathrm{SnO}_{2}$ ま たは $\alpha-\mathrm{Bi}_{2} \mathrm{O}_{3}$ の混合物からなっていることがわかった。 


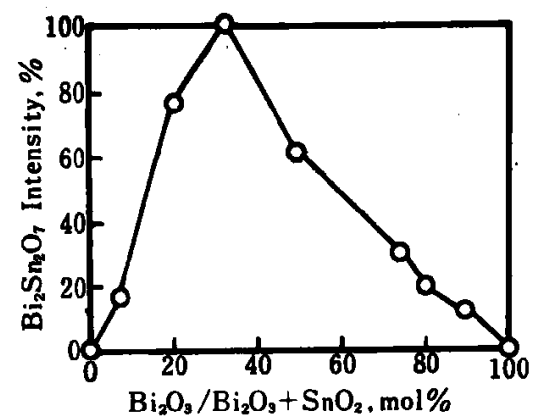

Fig. 4 The Relative Intensity of $\mathrm{Bi}_{3} \mathrm{Sn}_{8} \mathrm{O}_{7}$ Formed in $\mathrm{Bi}_{2} \mathrm{O}_{2}-\mathrm{SnO}_{2}$ Catalysts

それぞれの焼成物中の $\mathrm{Bi}_{2} \mathrm{Sn}_{2} \mathrm{O}_{7}$ の含有率を回折線の強度か ら测定した結果は Fig.4のとおりである。

これと Fig. 1 に示した転化率，選抧率とはよく対応してお り $\mathrm{Bi}_{2} \mathrm{Sn}_{2} \mathrm{O}_{7}$ がトルエンの酸化脱水素二量化反応の主な活性種 であることを示唆している。

このことは次の事実によっても衰付けられる。すなわち $\mathrm{Bi}_{2} \mathrm{O}_{3}$ 含有率 $33 \mathrm{~mol} \%$ の混合物を種々の温度で 1 時間焼成し， 焼成物中の $\mathrm{Bi}_{2} \mathrm{Sn}_{2} \mathrm{O}_{7}$ の量を测定した。一方これらの焼成物を 触媒としてトルエンの酸化脱水素二量化反応を行った。Fig. 5 に示すように $\mathrm{Bi}_{2} \mathrm{Sn}_{2} \mathrm{O}_{7}$ 含有事の增加とともにトルエン転化率, 脱水素二量体選択率が增大している。
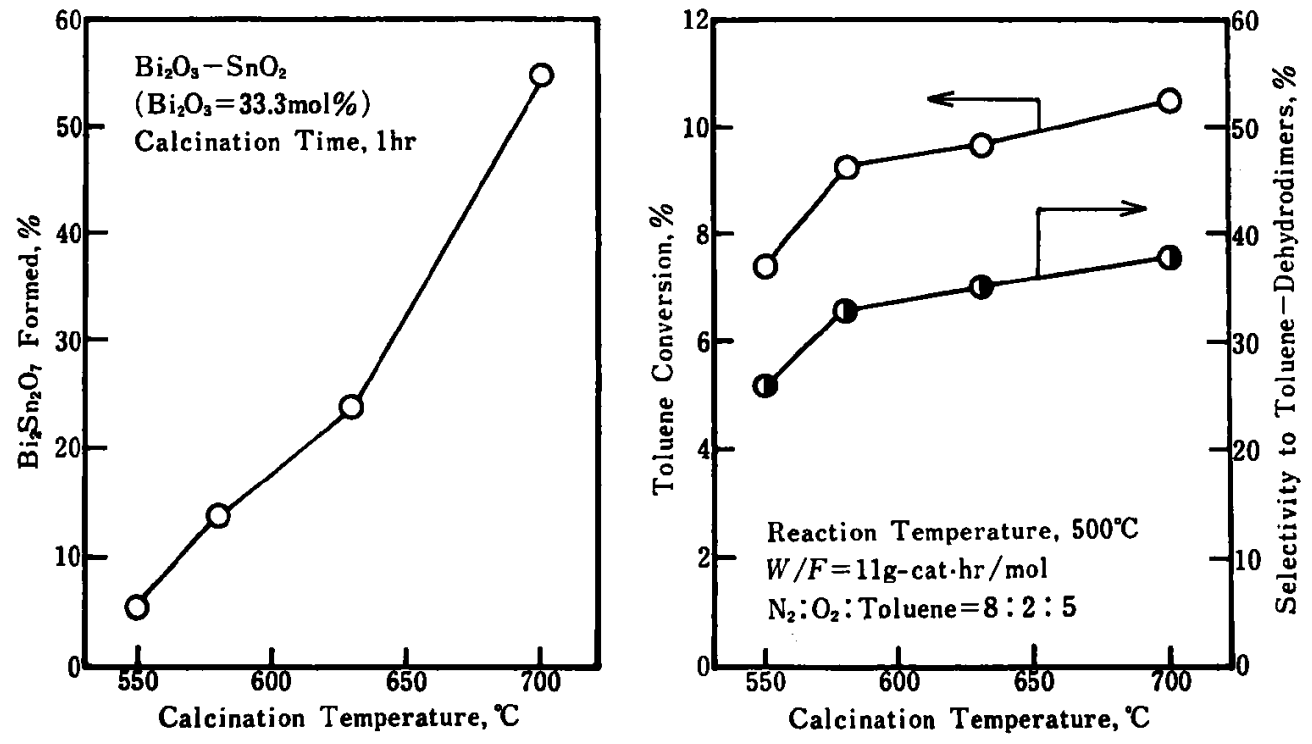

Fig. 5 Correlation between $\mathrm{Bi}_{2} \mathrm{Sn}_{2} \mathrm{O}_{7}$ Content and Activity in $\mathrm{Bi}_{2} \mathrm{O}_{2}-\mathrm{SnO}_{2}\left(\mathrm{Bi}_{8} \mathrm{O}_{8}=33.3 \mathrm{~mol} \%\right)$ Catalysts

\section{3 トルエンの酸化脱水素二吾化反応における $\mathrm{Bi}_{2} \mathrm{Sn}_{2} \mathrm{O}_{7}$ 出某の形蝶変化}

$$
\mathrm{Bi}_{2} \mathrm{Sn}_{2} \mathrm{O}_{7} \rightarrow \mathrm{SnO}_{2}+\mathrm{Bi}_{12} \mathrm{SnO}_{20}+r-\mathrm{Bi}_{2} \mathrm{O}_{3}
$$

で,これらの酸化物の生成量の 相対的な比較はできない。 一方トルエン転化率および脱水素二量体選択率の経時変化は
$\mathrm{Bi}_{2} \mathrm{O}_{3}$ 含有率 $33.3 \mathrm{~mol} \%$ の $\mathrm{Bi}_{2} \mathrm{O}_{3}-\mathrm{SnO}_{2}$ 混合物を $700^{\circ} \mathrm{C}$ で 6 時 間焼成してつくった $\mathrm{Bi}_{2} \mathrm{Sn}_{2} \mathrm{O}_{7}$ を触 媒としてトルエンの酸化脱水素二至 化を行い,触媒の経時による形態変 化，トルエン転化事，脱水素二量体 遙択率の経時変化を調へた。

トルエンを $500^{\circ} \mathrm{C}$ で反応させた時 の蚛媒の形䧳変化は Fig. 6 の通り である。
Table 2 Change of $\mathrm{Bi}_{2} \mathrm{Sn}_{2} \mathrm{O}_{7}$ Catalyst during the Oxidative Dehydrodimerization of Toluene Reaction Condition :Temperature, $500^{\circ} \mathrm{C}$ or $600^{\circ} \mathrm{C} ; \mathrm{W} / \mathrm{F}, 11 \mathrm{~g}-\mathrm{cat} \cdot \mathrm{hr} / \mathrm{mol} ; \mathrm{N}_{2}: \mathrm{O}_{2}:$ Toluene $=8: 2: 5$

\begin{tabular}{c|c|c|c|c|c|c}
\hline \multirow{2}{*}{$\begin{array}{c}\text { Reaction } \\
\text { Time } \\
(\mathrm{hr})\end{array}$} & Converted $\mathrm{Bi}_{2} \mathrm{Sn}_{2} \mathrm{O}_{7}(\mathscr{\sigma})$ & \multicolumn{4}{|c}{ Relative Intensity of Diffraction Patterns * } \\
\cline { 2 - 7 } & $\begin{array}{c}\text { at } \\
500^{\circ} \mathrm{C}\end{array}$ & $\begin{array}{c}\text { at } \\
600^{\circ} \mathrm{C}\end{array}$ & $\begin{array}{c}\mathrm{SnO}_{2} \\
\text { at } 2 \theta=33.9^{\circ}\end{array}$ & $\begin{array}{c}r-\mathrm{Bi}_{2} \mathrm{O}_{3} \\
\text { at } 2 \theta=32.8^{\circ}\end{array}$ & $\begin{array}{c}\mathrm{Bi}_{12} \mathrm{SnO}_{20} \\
\text { at } 2 \theta=31.8^{\circ}\end{array}$ & $\begin{array}{c}\mathrm{Bi}_{12} \mathrm{SnO}_{20}+r-\mathrm{Bi}_{2} \mathrm{O}_{3} \\
\text { at } 2 \theta=28.1^{\circ}\end{array}$ \\
\hline 1 & 15 & 69 & 0.76 & 0.43 & 0.31 & 0.40 \\
3 & - & 91 & 0.81 & 0.77 & 0.67 & 0.82 \\
6 & - & 93 & 0.89 & 0.79 & 0.77 & 0.83 \\
12 & 35 & 94 & 1 & 1 & 1 & 1 \\
\hline
\end{tabular}




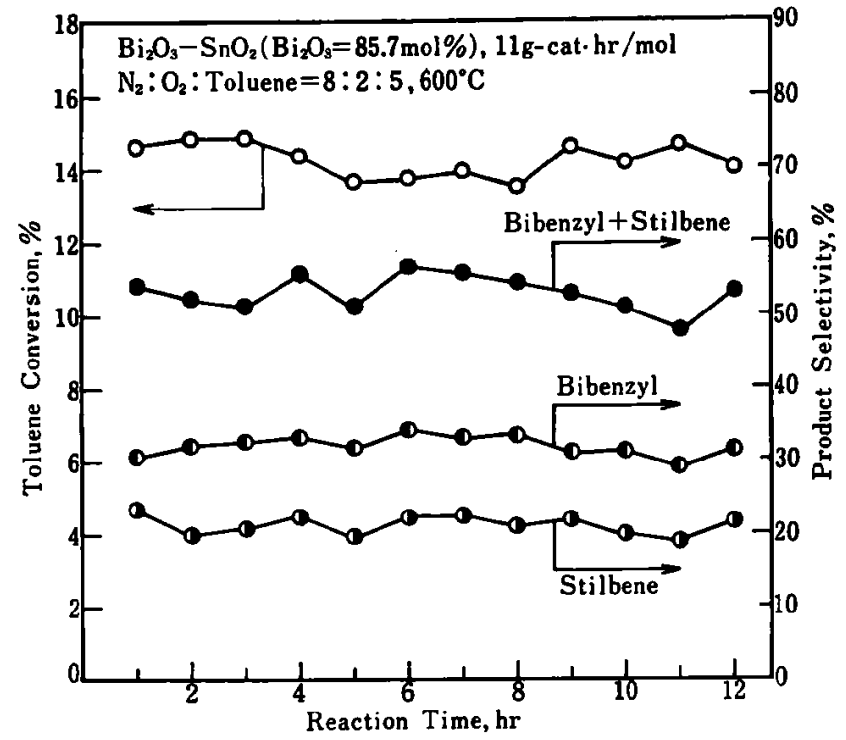

Fig. 7 Activity of $\mathrm{Bi}_{2} \mathrm{Sn}_{2} \mathrm{O}$, Catalyst for Oxidative Dehydrodimerization of Toluene

Fig. 7 の通りである。

転化率, 選択率ともにいずれの反応温度においても経時変化 がない。特に $600^{\circ} \mathrm{C}$ の反応温度では主要な触媒活性種と考え ている $\mathrm{Bi}_{2} \mathrm{Sn}_{2} \mathrm{O}_{7}$ が 3 時問で 90\% 消失しているにもかかわら ず, 本化率, 選报率ともに反応初期と变わらず,むしろわずか ではあるが上䄯する㑯向にある。

この現象は $\mathrm{Bi}_{2} \mathrm{Sn}_{2} \mathrm{O}_{1}$ が変化して生成した $\mathrm{Bi}_{12} \mathrm{SnO}_{20} や \tau^{-}$ $\mathrm{Bi}_{2} \mathrm{O}_{3}$ もトルエンの酸化脱水素二量化に対して活性であると解 釈すれば説明がっく。

$\mathrm{Bi}_{2} \mathrm{O}_{3}$ 含有率の高い $\mathrm{Bi}_{2} \mathrm{O}_{3}-\mathrm{SnO}_{2}$ 混合物を触媒として反応さ せた場合には， $\mathrm{Bi}_{12} \mathrm{SnO}_{20}$ を多く含んだ触媒が得られるかも知 れない。そこでまず種々の組成の $\mathrm{Bi}_{2} \mathrm{O}_{3}-\mathrm{SnO}_{2}$ 混合物を触媒と して $550^{\circ} \mathrm{C}$ および $600^{\circ} \mathrm{C}$ において反応を行い，触媒原料組成 と活性, 選択性の関係を再度調べた。その結果を Fig. 8 に示 す。

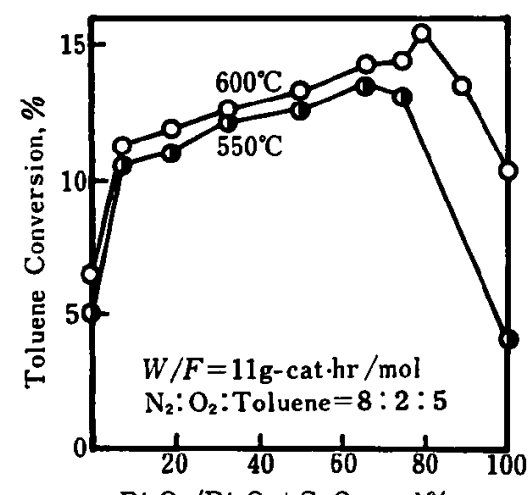

$\mathrm{Bi}_{2} \mathrm{O}_{3} / \mathrm{Bi}_{2} \mathrm{O}_{3}+\mathrm{SnO}_{2}, \mathrm{~mol} \%$

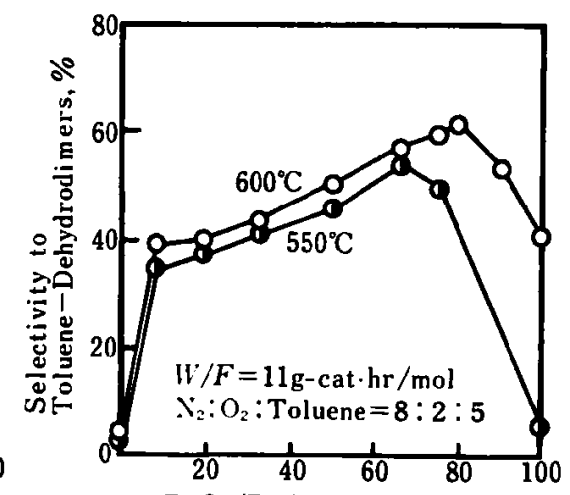

$\mathrm{Bi}_{2} \mathrm{O}_{3} / \mathrm{Bi}_{2} \mathrm{O}_{3}+\mathrm{SnO}_{2}, \mathrm{~mol} \%$

Fig. 8 Activity of $\mathrm{Bi}_{8} \mathrm{O}_{3}-\mathrm{SnO}_{2}$ Catalysts for Oxidative Dehydrodimerization of Toluene at $550 \sim 600^{\circ} \mathrm{C}$

反応温度の上昇とともに転化率, 選択率が上昇する。また $550^{\circ} \mathrm{C}$ に拈いて転化率, 選択率が最高を示寸組成は $\mathrm{Bi}_{2} \mathrm{O}_{3}$ 含有 率 $67 \mathrm{~mol} \%$ ，600 $\mathrm{C}$ におけるそれは $80 \mathrm{~mol} \%$ であり，最高活 性を示す触媒組成は反応温度の上昇とともに $\mathrm{Bi}_{2} \mathrm{O}_{3}$ 含有率の 多い方に移っている。このことは $\mathrm{Bi}_{12} \mathrm{SnO}_{20}$ \& $r-\mathrm{Bi}_{2} \mathrm{O}_{3}$ も活 性種として作用し，それらの活性は $\mathrm{Bi}_{2} \mathrm{Sn}_{2} \mathrm{O}_{7}$ による反底より もより高温において䫓著になることを示唆するものであろう。
85.7 molqh の $\mathrm{Bi}_{2} \mathrm{O}_{3}$ を含む $\mathrm{Bi}_{2} \mathrm{O}_{3}-\mathrm{SnO}_{2}$ 混合物を $700^{\circ} \mathrm{C}$ で 6 時間焼成し， $\mathrm{X}$ 線回折により焼成物の化合形態を調べると $\mathrm{Bi}_{2} \mathrm{Sn}_{2} \mathrm{O}_{7}$ および $\alpha-\mathrm{Bi}_{2} \mathrm{O}_{3}$ からなっていることがわかった。原 料組成から $\mathrm{Bi}_{2} \mathrm{Sn}_{2} \mathrm{O}_{7}$ の含有种は 13.996 となる。

この触媒によるトルエンの酸化脱水素二量化反応を $600^{\circ} \mathrm{C}$ で 行い，転化率，選択率の経時変化，および触媒の形態変化を調 ベた。

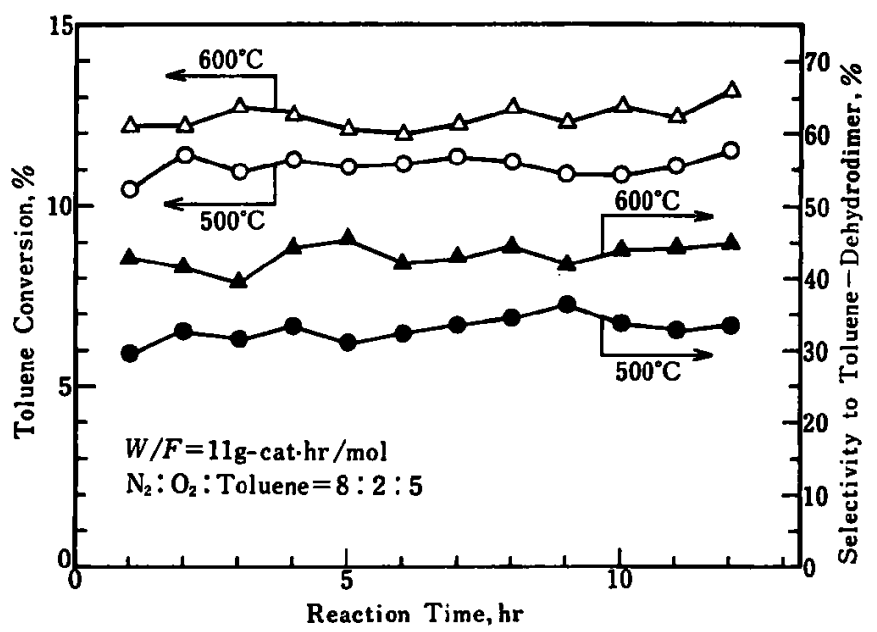

Fig. 9 Activity of $\mathrm{Bi}_{2} \mathrm{O}_{8}-\mathrm{SnO}_{2}\left(\mathrm{Bi}_{2} \mathrm{O}_{8}=85.7\right.$ mol\%) Catalyst for Oxidative Dehydrodimerization of Toluene

Table 3 Change of $\mathrm{Bi}_{2} \mathrm{Sn}_{2} \mathrm{O}_{7}$ in $\alpha-\mathrm{Bi}_{2} \mathrm{O}_{3}+\mathrm{Bi}_{2} \mathrm{Sn}_{2} \mathrm{O}_{7}(11: 1$ molar ratio) Catalyst System during the Oxidative Dehydrodimerization of $\mathrm{T}$ oluene

Reaction Condition : Temperature, $600^{\circ} \mathrm{C}: W / F=11 \mathrm{~g}-\mathrm{cat} \cdot \mathrm{hr} / \mathrm{mol}$ $\mathrm{N}_{2}: \mathrm{O}_{2}:$ Toluene $=8: 2: 5$

\begin{tabular}{c|c|c}
\hline $\begin{array}{c}\text { Reaction Time } \\
(\mathrm{hr})\end{array}$ & $\mathrm{Bi}_{2} \mathrm{Sn}_{2} \mathrm{O}_{7}$ Content & $\begin{array}{c}\mathrm{Bi}_{2} \mathrm{Sn}_{2} \mathrm{O}_{7} \text { Converted } \\
(\mathscr{6})\end{array}$ \\
\hline 0 & 13.9 & - \\
1 & 11.4 & 18 \\
3 & 7.6 & 45 \\
6 & 8.4 & 40 \\
12 & 5.0 & 64 \\
\hline
\end{tabular}

Fig. 9 に示すように転化率，選択率は $\mathrm{Bi}_{2} \mathrm{Sn}_{2} \mathrm{O}^{\prime}$ 触媒による場合より若干増大しこれらの経時変 化もほとんど認められなかった。

反応の進行とともに金属 $\mathrm{Bi}$ の析出が認められ た。これは $\sigma-\mathrm{Bi}_{2} \mathrm{O}_{3}$ のトルエンによる這元によ り生成したものと考えられる。経時による触媒の 形態変化は $\alpha-\mathrm{Bi}_{2} \mathrm{O}_{3}$ および金属 $\mathrm{Bi}$ の回折線が他 の金属酸化物のそれと重なるため， $\mathrm{Bi}_{2} \mathrm{Sn}_{2} \mathrm{O}$ ，お よび $\mathrm{SnO}_{2}$ を除いては十分な知見が得られなかっ た。 $\mathrm{Bi}_{2} \mathrm{Sn}_{2} \mathrm{O}_{7}$ 含有量の経時変化は Table 3 の とおりである。

この結果を Table 2 と比較すると $\mathrm{Bi}_{2} \mathrm{Sn}_{2} \mathrm{O}_{7}$ の 変化量が著しく少なくなっていることがわかる。 これは反応系で次の変化を起こしているためと考えられる。

i ) $\mathrm{Bi}_{2} \mathrm{Sn}_{2} \mathrm{O}_{7}$ は酸素存在下でトルエンを酸化し，脱水素二 量体その他を生成し，それ自身は $r-\mathrm{Bi}_{2} \mathrm{O}_{3}, \mathrm{Bi}_{12} \mathrm{SnO}_{20}$ ，および $\mathrm{SnO}_{2}$ になる。

ii ） i）で生成した $\mathrm{SnO}_{2}$ は $\alpha-\mathrm{Bi}_{2} \mathrm{O}_{3}$ と反応して $\mathrm{Bi}_{2} \mathrm{Sn}_{2} \mathrm{O}_{\text {， }}$ を再生する。

この触媒は $\mathrm{Bi}_{2} \mathrm{Sn}_{2} \mathrm{O}_{7}$ に対して 11 倍 $\mathrm{mol}$ の $a-\mathrm{Bi}_{2} \mathrm{O}_{3}$ を 
含んでいる。したがって反応の比较的初期段階においては $\mathrm{Bi}_{2} \mathrm{Sn}_{2} \mathrm{O}_{7}$ の量が一定であると予想される。しかし実際には Table 3 に示すように $\mathrm{Bi}_{2} \mathrm{Sn}_{2} \mathrm{O}_{7}$ の含有量は徐々に低下してい る。これは ii）の反応が遅いこと, て金属 Bi に還元されることによるものと考えられる。

\section{4 トルエンの酸化脱水素二量化における $\mathrm{Bi}_{2} \mathrm{O}_{3}-\mathrm{SnO}_{2}$ 触媒の活性種}

Fig. 1 および8に示すように $\mathrm{SnO}_{2}$ の酸化脱水素二量化活 性は低い。一方 $\alpha-\mathrm{Bi}_{2} \mathrm{O}_{3}$ の活性は低温 $\left(500^{\circ} \mathrm{C}\right)$ においては低 いが反応温度の上䄯とともに著しく増大する。

また $700^{\circ} \mathrm{C}$ で焼成した $\mathrm{SnO}_{2}$ と $\alpha-\mathrm{Bi}_{2} \mathrm{O}_{3}$ を $\mathrm{Bi}: \mathrm{Sn}$ 原子比 1:1 で物理的に混合した触媒の活性はそれぞれ単独金属酸化 物の活性の和にほぼ等しい。一方 $\mathrm{SnO}_{2}$ と $\mathrm{Bi}_{2} \mathrm{O}_{3}$ の混合物を 焼成してつくった $\mathrm{Bi}_{2} \mathrm{Sn}_{2} \mathrm{O}_{7}$ の活性は単独酸化物の活性よりも 著しく高い。これは $\mathrm{Bi}_{2} \mathrm{Sn}_{2} \mathrm{O}_{7}$ が酸化脱水素二量化反応の主た る活性種の一つであることを示す。

一方高温 $\left(600^{\circ} \mathrm{C}\right)$ においては $\mathrm{SnO}_{2}: \mathrm{Bi}_{2} \mathrm{O}_{3}$ がほぼ $2: 8 \mathrm{~mol}$ 比の触媒が最も活性が高い。このことは前節で述べたよ5に $r-\mathrm{Bi}_{2} \mathrm{O}_{3}$ または $\mathrm{Bi}_{12} \mathrm{SnO}_{20}$ が高温において主たる活性種になっ ていることを示す。

$\alpha-\mathrm{Bi}_{2} \mathrm{O}_{3}$ 触媒および $\mathrm{Bi}_{2} \mathrm{Sn}_{2} \mathrm{O}_{7}+\alpha-\mathrm{Bi}_{2} \mathrm{O}_{3}$ からなる触媒によ る反応では，時間の程過とともに金属 $\mathrm{Bi}$ が析出する。この㑯 向は酸素非存在下において著しく，また活性も低下する。 $\mathrm{Bi}_{2} \mathrm{Sn}_{2} \mathrm{O}_{7}$ による酸素非存在下の反応においても同じ傾向を示 す。

これらのことからトルエンの酸化脱水素二量化に関与するの は $\mathrm{Bi}$ に結合している格子酸素であることを示す。 $\alpha-\mathrm{Bi}_{2} \mathrm{O}_{3}$ 触 媒の酸素存在下高温における活性が著しく増大するのは析出し た金属 $\mathrm{Bi}$ の再酸化が比較的早く起こるためと考えられる。

$\mathrm{Bi}_{2} \mathrm{Sn}_{2} \mathrm{O}_{7}$ または $\mathrm{Bi}_{2} \mathrm{Sn}_{2} \mathrm{O}_{7}+\mathrm{SnO}_{2}$ 触媒による反応では金属 $\mathrm{Bi}$ の析出が認められない。これは $\mathrm{SnO}_{2} か ゙$ 金属 $\mathrm{Bi}$ の再酸化 に対して奇与しているためと考えられる。Fig. 4 からわかる ように約 5 molg の $\mathrm{Bi}_{2} \mathrm{O}_{3}$ を含む触媒の $\mathrm{Bi}_{2} \mathrm{Sn}_{2} \mathrm{O}_{7}$ の含有量 は, 約 $80 \mathrm{~mol} / \%$ の $\mathrm{Bi}_{2} \mathrm{O}_{3}$ を含む触媒の $\mathrm{Bi}_{2} \mathrm{Sn}_{2} \mathrm{O}$ ，の含有量と 同しであるが, $500^{\circ} \mathrm{C}$ における前者の活性は Fig. 1 に示した よらに後者がそれに対して 2.5 3 倍高い。このことむ反応に 対する $\mathrm{SnO}_{2}$ の奇与を示している。

トルエンによる $\alpha-\mathrm{Bi}_{2} \mathrm{O}_{3}$ や $\mathrm{Bi}_{2} \mathrm{Sn}_{2} \mathrm{O}_{7}$ の還元は非常にはやく 進行する。一方 $\mathrm{SnO}_{2}$ の遗元では低級すず酸化物または金属 すす゚の存在は確認できなかった。これらはプロピレンによる
$\mathrm{Bi}_{2} \mathrm{O}_{3}$ の還元が容易に起こり，内部まで進行しているのに対 し, $\mathrm{SnO}_{2}$ の還元が表面第一層でとまるという麻生らの研究結 果と類似している10)。

一方, $\mathrm{SnO}_{2}$ は気相中の ${ }^{18} \mathrm{O}_{2}$ と $500^{\circ} \mathrm{C} て ゙$ 速やかに酸素交换 反応を起こすことが知られている(1)。従って $\mathrm{Bi}_{2} \mathrm{O}_{3}-\mathrm{SnO}_{2}$ 触媒 において遗元によって生成した金属 $\mathrm{Bi}$ の再酸化は, $\mathrm{SnO}_{2}$ に 吸着され活性化された気相酸素が $\mathrm{Bi}$ 側に移行することによっ て起こるものと考えられる。

これらのことから $\mathrm{SnO}_{2}$ は金属 $\mathrm{Bi}$ の再酸化のための活性 酸素遍伝体となっていると考えられる。このよ5な理由から $\mathrm{SnO}_{2}$ 含有量の 少ない $\mathrm{Bi}_{2} \mathrm{Sn}_{2} \mathrm{O}_{7}+\alpha-\mathrm{Bi}_{2} \mathrm{O}_{3}$ 系触媒においては 反応の時間経過とともに金属 $\mathrm{Bi}$ の析出が多くなるものと考え られる。

\section{4 結 論}

種々の混合比をむつ $\mathrm{Bi}_{2} \mathrm{O}_{3}-\mathrm{SnO}_{2}$ 触媒のトルエン酸化脱水素 二量化活性およびその化合形態を調べた。その結果, トルエン の酸化脱水素二量化に対して $500^{\circ} \mathrm{C}$ では $\mathrm{Bi}_{2} \mathrm{Sn}_{2} \mathrm{O}_{7}$ が, $600^{\circ} \mathrm{C}$ では $\alpha-\mathrm{Bi}_{2} \mathrm{O}_{3}, \mathrm{Bi}_{12} \mathrm{SnO}_{20}$, および $\gamma-\mathrm{Bi}_{2} \mathrm{O}_{3}$ が主活性種である ことがわかった。

なお還元反応などを合わせて調べた結果，以下の反応機構が 推定された。トルエンが Bik結合している格子酸素によって 酸化脱水素され，ベンジル中間体を生じここれが二量化してビ ベンジル，さらにスチルベンが生成する。また逥元された $\mathrm{Bi}$ は $\mathrm{SnO}_{2}$ によって活性化された気相酸素により再び酸化され る。このような酸化僄元機構で接触反応が進行する。

\section{文献}

1) Sakamoto, T., Egashira, M., Seiyama, T., J. Catalysis, 16, 407 (1970).

2）大段, 小川, 梅村, 山田, 工化, 73, 842 (1970).

3) Trimm, D.L., Doerr, L.A., Chem. Commun., 1970, 1303.

4）清山，宇田，石油誌，15，(5)，346 (1972).

5) Liu, K.H.D., Masuda, A., Yamazaki, Y., Tetrahedron Letters, 1975, 3007.

6) Liu, K.H.D., Yamazaki, Y., Bull. Japan Petrol. Inst., 18, (1), 45 (1976).

7) ASTM X-ray Powder Data File, No. 17-457.

8) ibid., No. 17-805.

9) ibid., No. 2-542.

10）麻生, 中尾, 江頭, 山添, 清山, 触媒, 18，(4)（第 39 回触媒 封論会予稿集) 106 P (1976).

11) Winter, E.R.S., J. Chem. Soc., A 2889 (1968). 